\title{
Cougar (Puma concolor) vocalization and frequency shift as a playback response
}

\author{
Arthur Macarrão $o^{1,4}$, Milena Corbo $^{2}$ \& Carlos Barros de Araújo ${ }^{3}$ \\ ${ }^{I}$ Departamento de Biologia Animal, Instituto de Biologia, Universidade Estadual de \\ Campinas - UNICAMP, Rua Monteiro Lobato, 255, CEP 13083-862, Campinas, SP, Brasil \\ ${ }^{2}$ Fonoteca Neotropical Jacques Vielliard, Departamento de Biologia Animal, Instituto de Biologia, \\ Universidade Estadual de Campinas - UNICAMP, Campinas, SP, Brasil \\ ${ }^{3}$ Departamento de Sistemática e Ecologia, Centro de Ciências Exatas e da Natureza, \\ Universidade Federal da Paraíba - UFPB, Campus I, CEP 58059-900, João Pessoa, PB, Brasil \\ ${ }^{4}$ Corresponding autor: Arthur Macarrão, e-mail: amacarrao@gmail.com
}

MACARrÃO, A., CORBO, M. \& ARAÚJO, C.B. Cougar (Puma concolor) vocalization and frequency shift as a playback response. Biota Neotrop. 12(3): http://www.biotaneotropica.org.br/v12n3/en/ abstract?article+bn03212032012

Abstract: Recordings of cougar (Puma concolor) vocalizations are rare in the wild. We made two night recordings from the same individual. The first recording was spontaneous whereas the second was made after a playback emission (using a third party recording) allowing for comparisons. We measured the calls before and after playback stimuli using Raven software and noted that only the minimum fundamental frequency presented differences between calls. As fundamental frequency is closely related to body size, a frequency reduction may indicate territoriality engagement. Our recording seems to be the first held in the Brazilian wild. Little is known about cougar natural history and behavior, and our data suggest that acoustic communication may have an important role on the species intraspecific interactions.

Keywords: bioacoustics, felid, recordings, Brazil, acoustic communication.

MACARRÃO, A., CORBO, M. \& ARAÚJO, C.B. Vocalização da onça-parda (Puma concolor) e mudança de frequência como resposta ao playback. Biota Neotrop. 12(3): http://www.biotaneotropica.org.br/v12n3/pt/ abstract?article+bn03212032012

Resumo: Registros de vocalizações de onça-parda (Puma concolor) são raros na natureza. Fizemos uma gravação espontânea da espécie à noite, em seguida tocamos o playback com uma gravação prévia disponível em bibliografia, o que fez com que a onça-parda se aproximasse e vocalizasse, permitindo que pudéssemos gravar novamente e assim comparar. Comparamos os chamados antes e depois do estímulo do playback, usando o programa Raven, e constatamos que somente a frequência fundamental mínima apresentou diferenças entre os chamados. Como a frequência fundamental está diretamente relacionada com o tamanho corporal, uma redução neste parâmetro pode significar defesa territorial. Nossas gravações aparentemente são as primeiras realizadas na natureza no Brasil. Pouco se sabe sobre história natural e comportamento da onça parda no Brasil, e nossos dados sugerem que a comunicação acústica tem um papel importante nas interações intraespecíficas desta espécie.

Palavras-chave: bioacústica, felino, gravação, Brasil, comunicação acústica. 


\section{Introduction}

The Cougar (Puma concolor Linnaeus, 1771) has the widest distribution among felids in Americas and has the greatest range of any large wild terrestrial mammal in the Western Hemisphere, living in many kinds of habitats, ranging from the southern Chile (Patagonia) across North America from the Pacific to the Atlantic, covering the wider range of latitude than any other wild felid (Wainwright et al. 2010). It's the second largest felid in Brazil, weighting from 22 to $74 \mathrm{~kg}$ and presenting a length of 0.9 to $2.30 \mathrm{~m}$. It has solitary and terrestrial habits, with diurnal and nocturnal activities, and a diversified and adaptable diet (Cheida et al. 2011).

Despite its wide distribution, the Cougar is locally rare, threatened by hunting, loss of habitat and prey shortage (Emmons \& Feer 1997). The size of the species and type of diet requires large home ranges (Mazzoli 1993). It is threatened of extinction in Brazil as "vulnerable" (Sana \& Cullen 2008). Only a few studies were made all over South America, which includes systematics (e.g. Cabrera 1957), growth rates (e.g. Ximenez 1972), use of habitat (e.g. Courtin et al. 1980), but most studies are concentrated in cougar's diet (e.g. Yáñez et al. 1986, Emmons 1987, Rau \& Jiménez 2002, Villepique et al. 2011). In southeast Brazil the taxa is Puma concolor capricornensis, considered as vulnerable especially due to habitat loss (Mazzoli 1993).

Records of Puma concolor vocalizations are rare in the wild (Smallwood 1993, McCollough 2011). Most encounters with the species consist in quick sightings. The few recordings of the species vocalization comprehend scattered reports that include captivity recordings (Rabb 1959).

There are several types of vocalizations in $P$. concolor acoustic communication such as vocalization of the female estrus, purring, contact with juvenile and vocalizations uttered during hunts or persecution (Smallwood 1993, Peters 2002, Potter 2002). There are also reports that the cougar may mimic their prey vocalizations in the Amazon rainforest (Calleia et al. 2009). This indicates a complex acoustic communication system yet to be accurately described.

Considering the small number of studies on the acoustic communication of wild cats, we here describe the vocalization of a Puma concolor made in the Brazilian wild, comparing vocalization before and after playback stimuli.

\section{Materials and Methods}

We made a spontaneous recording of Puma concolor on March $13^{\text {th }} 2010$ at night at Artur Nogueira city, São Paulo, Brazil (22 $38^{\circ}$ $07^{\prime \prime} \mathrm{S}$ and $\left.47^{\circ} 08^{\prime} 18^{\prime \prime} \mathrm{W}\right)$. We were on a dirt road between a forest fragment and sugar cane plantation and the animal was around $60 \mathrm{~m}$ away from the recordist. After a few minutes recording, we made a playback from Emmons \& Feer (1997). A few minutes after the playback stimuli, the cougar approached and vocalized, allowing us to record it again, now around $30 \mathrm{~m}$ away from the recordist. We then turned the car lights on and saw the animal, which immediately ran in the opposite direction. The recordings were made with Sennheiser ME67 directional microphone and Marantz PMD 671 digital recorder. Recordings are deposited in the Fonoteca Neotropical Jacques Vielliard of Universidade Estadual de Campinas, Brazil, record number FNJV 12910 (before playback) and FNJV 12911 (after playback).

Based on comparisons (Potter 2002) we assumed that both vocalizations recorded corresponded to an adult, maybe a female in estrus. However, due to the lack of knowledge on the species communication and its vocal repertoire, we may not be certain of this.

We measured the calls using Raven software (FFT size of 1200) and made the statistical analyses using Statistica 7.0. We made the spectrograms with Soundruler (FFT size of 512). Data is presented as mean ( \pm standard deviation). We compared vocalizations using Mann-Whitney test, with the use of the Bonferroni correction for significance threshold (attaining an $\alpha=0.0125$ ).

\section{Results}

The call is rich in harmonics and presents frequency modulation, resulting in the form of an inverted "U" on the spectrogram (Figure 1). The first vocalization, without playback, lasted 83 seconds (36 calls). Playback induced the cougar's approach, as well as the uttering of a second vocalization, which lasted 73 seconds (36 calls). Only the minimum fundamental frequency presented differences between calls $(\mathrm{p}=0.004)$ among the parameters analysed (Table 1, Figure 2).

Table 1. Call parameters of Puma concolor before and after playback stimulus.

\begin{tabular}{lcc}
\hline \multicolumn{1}{c}{ Parameters } & $\begin{array}{c}\text { Before } \\
\text { playback }\end{array}$ & $\begin{array}{c}\text { After } \\
\text { playback }\end{array}$ \\
\hline Vocalization duration (seconds) & 83 & 73 \\
Number of calls & 36 & 36 \\
Calls average duration (seconds) & $0.65(0.38)$ & $0.60(0.22)$ \\
Min. FF (Hz) & $291(49)$ & $265(58)$ \\
Max. FF (Hz) & $438(31)$ & $425(30)$ \\
Emission rate (Hz) & $0.55(0.22)$ & $0.56(0.21)$ \\
\hline
\end{tabular}

Min. FF: minimal fundamental frequency; Max. FF: maximum
fundamental frequency.

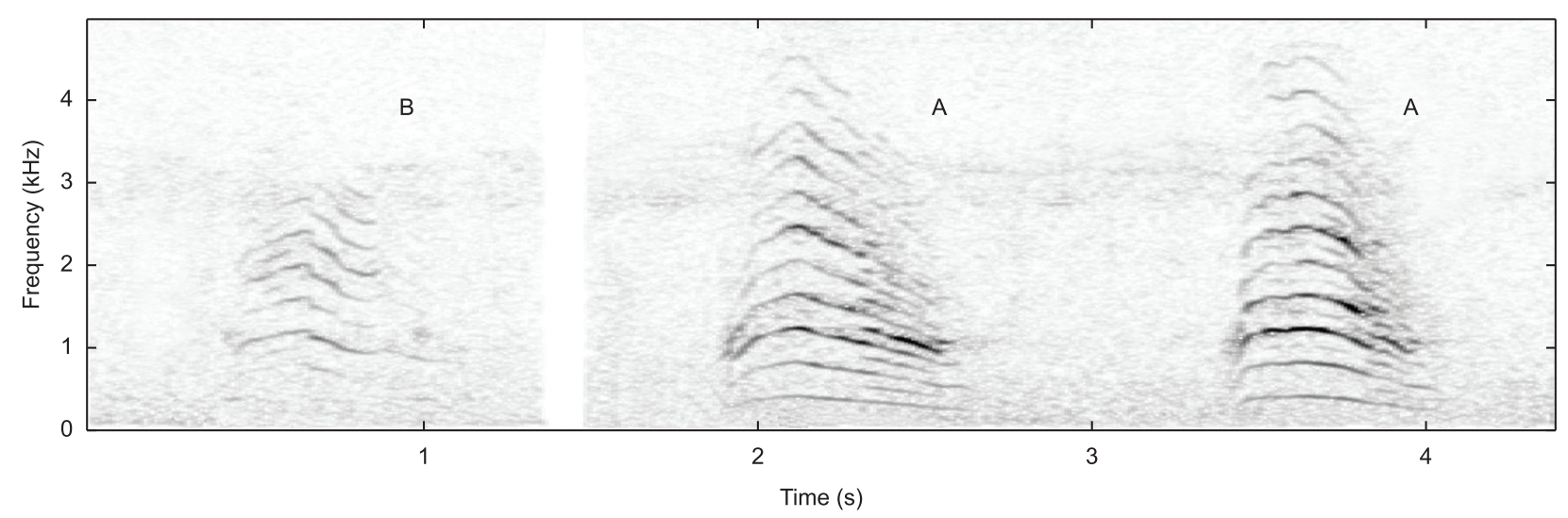

Figure 1. Spectrogram of Puma concolor before (B) and after (A) playback at Artur Nogueira, SP, Brazil. 


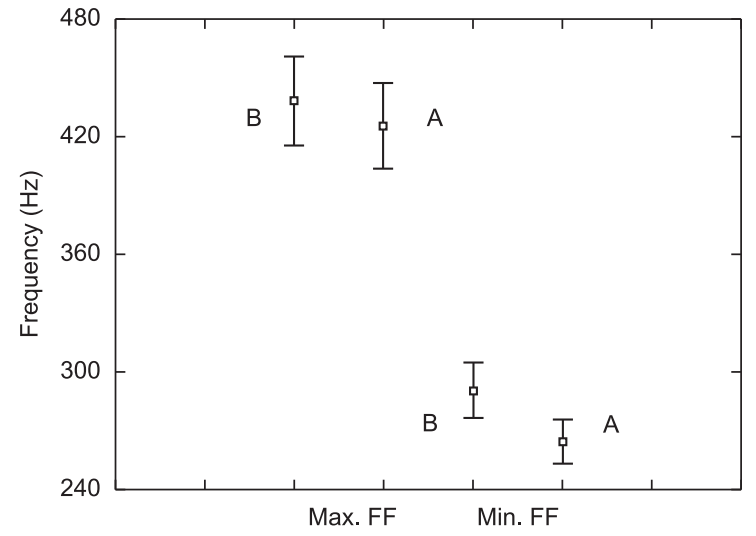

Figure 2. Frequencies values before (B) and after (A) playback for maximum fundamental frequency (Max. FF) and minimum fundamental frequency (Min. FF).

\section{Discussion}

Territorial behavior may help explain the differences found between the minimum fundamental frequency, as frequency is negatively correlated to body size (Fletcher 2004) and animals may issue lower frequencies to intimidate a possible rival. As fundamental frequency is closely related to body size, a frequency reduction may indicate territoriality engagement and body mass signaling. Moreover, in spite of the frequency variation found before and after the playback stimuli, the call should be an honest signal of body size, as the animals seems to shift the fundamental frequency to its lowest limit, which should be morphologically determined by body size. That way body size will be the main restriction to frequency shift, so that the larger the animal, the lower the minimum fundamental frequency uttered.

Electronic call boxes have been used successfully to lure puma into snare sites by using prey (e.g., fawn bleats) or puma vocalizations (e.g., screams, yowling). Programmable call boxes that allow vocalizations to be played at specific intervals for short periods (e.g., 30 seconds every hour from 10:00 PM to 6:00 AM) are effective and useful while a reliable attractant is not developed (Shaw et al. 2007).

Our recording appears to be the first held in Brazil in the wild. Despite being a common species, with large distribution in the country (Sana \& Cullen 2008), as other top carnivores, it occurs at low densities (Wainwright et al. 2010) so that little is known about its natural history and behavior, and the available data comes from captive individuals or monitored by tracks, cameras trap and telemetry (Rabb 1959, Shaw et al. 2007). Our data indicates that acoustic communication may have a central role within the species intraspecific interactions. That way, more studies are necessary to properly describe the role of acoustic communication on aspects of species biology such as mate attraction or territoriality.

\section{Acknowledgements}

We are grateful to Peter Crawshaw, Gustav Peters and Marcel Penteado for the help and additional information.

\section{References}

CABRERA, A. 1957. Catalogo de los mamíferos de America del Sur. Rev. Mus. Argent. Cienc. Nat. "Bernardino Rivadavia" 4(1):290-295.
CALLEIA, F.O., ROHE, F. \& GORDO, M. 2009. Hunting strategy of the Margay (Leopardus wiedii) to attract the Wild Pied Tamarin (Saguinus bicolor). Neotrop. Primates 16:32-34. http://dx.doi. org/10.1896/044.016.0107

CHEIDA, C.C., NAKANO-OLIVEIRA, E., FUSCO-COSTA, R., ROCHAMENDES, F. \& QUADROS, J. 2011. Ordem Carnivora. In Mamíferos do Brasil (N.R. Dos Reis, A.L. Peracchi, W.A. Pedro \& I.P. De Lima, eds.). 2. ed. Nelio R. dos Reis, Londrina, p.235-288.

COURTIN, S.L., PACHECO, N.V. \& ELDRIDGE, W.D.1980. Observaciones de alimentacion, movimientos y preferencias de habitat del puma, en el Islote Rupanco. Medio Amb. 4:50-55.

EMMONS, H.E. 1987. Comparative feeding ecology of felids in a neotropical rainforest. Behav. Ecol. Sociobiol. 20:71-283. http://dx.doi.org/10.1007/ BF00292180

EMMONS, L. \& FEER, F. 1997. Neotropical rainforest mammals: a field guide. 2nd ed. University of Chicago Press, Chicago.

FLETCHER, N.H. 2004. A simple frequency-scaling rule for animal communication. J. Acoust. Soc. Am. 115:2334-2338. PMid:15139646. http://dx.doi.org/10.1121/1.1694997

MAZZOLI, M. 1993. Ocorrência de Puma concolor (Linnaeus) (Felidae, Carnivora) em áreas de vegetação remanescente de Santa Catarina, Brasil. Rev. Bras. Zool. 10:581-587. http://dx.doi.org/10.1590/S010181751993000400002

McCOLlOUGH, M. 2011. Eastern puma (cougar) (Puma concolor couguar) 5-Year Review: Summary and Evaluation. U.S. Fish and Wildlife Service, Orono, Maine.

PETERS, G. 2002. Purring and similar vocalizations in mammals. Mamm. Rev. 32:245-271. http://dx.doi.org/10.1046/j.1365-2907.2002.00113.x

POTTER, J. 2002. Acoustical and functional analysis of Mountain lion Puma concolor vocalizations. J. Acoust. Soc. Am. 111:2393.

RABB, G.B. 1959. Reproductive and vocal behavior in captive pumas. J. Mammal. 40:616-617. http://dx.doi.org/10.2307/1376293

RAU, J.R. \& JIMÉNEZ, J.E. 2002. Diet of puma (Puma concolor, Carnivora: Felidae) in coastal and Andean ranges of Southern Chile. Stud. Neotrop. Fauna Environ. 37:201-205. http://dx.doi.org/10.1076/snfe.37.3.201.8567

SANA, D.A. \& CULLEN, L. 2008. Puma concolor capricorniensis. In Livro Vermelho da fauna Brasileira Ameaçada de Extinção (A.B.M. Machado, G. Drummond \& A.P. Paglia, eds.). Ministério do Meio Ambiente, Brasília; Fundação Biodiversitas, Belo Horizonte, p.795-797.

SHAW, H.G., BEIER, P., CULVER, M. \& GRIGIONE, M. 2007. Puma Field Guide. The Cougar Network, Concord, Massachusetts.

SMALLWOOD, K.S. 1993. Mountain Lion Vocalizations and Hunting Behavior. Southwest. Nat. 38:65-67. http://dx.doi.org/10.2307/3671647

VILLEPIQUE, J.T., PIERCE, B.M., BLEICH, V.C. \& BOWYER, R.T. 2011. Diet of Cougars (Puma concolor) following a decline in a population of Mule Deer (Odocoileus hemionus): lack of evidence for switching prey. Southwest. Nat. 56(2):187-192. http://dx.doi.org/10.1894/F07-TAL.1

WAINWRIGHT, C.J., DARIMONT, C.T. \& PAQUET, P.C. 2010. British Columbia's Neglected Carnivore: a Conservation Assessment and Conservation Planning Guide for Cougars. Raincoast Conservation Foundation, Sidney.

XIMENEZ, J.A. 1972. Notas sobre felidos neotropicales IV. Puma concolor ssp. en el Uruguay. Neotropica 18(55):37-39.

YÁÑEZ, J.L., CÁRDENAS, J.C., GEZZELE, P. \& JAKSIC, F.M. 1986. Food habits of the southernmost mountain lions (Felis concolor patagonica) in South America: Natural versus livestock ranges. J. Mammal. 67(3):604-606. http://dx.doi.org/10.2307/1381301 